Article

\title{
Soil Carbon Sequestration in Rainfed and Irrigated Production Systems in a New Brazilian Agricultural Frontier
}

\author{
Rafaella Campos*(D), Gabrielle Ferreira Pires and Marcos Heil Costa $\mathbb{D}$ \\ Department of Agricultural Engineering, Federal University of Viçosa, Viçosa MG 36570-900, Brazil; \\ gabrielle.pires@ufv.br (G.F.P.); mhcosta@ufv.br (M.H.C.) \\ * Correspondence: rafaella_campos@hotmail.com
}

Received: 28 February 2020; Accepted: 22 April 2020; Published: 7 May 2020

\begin{abstract}
Western Bahia, part of a large Brazilian agricultural frontier, is located mainly in fragile, sandy soils in a tropical seasonal climate with dry winters, characteristics that facilitate soil carbon loss. This study evaluates whether rainfed and irrigated agriculture in Western Bahia were able to sequester carbon and re-establish the soil organic carbon content (SOCC) lost due to land use change. Between 2010 and 2018, a total of 5469 soil samples were collected in the $0.00-0.20 \mathrm{~m}$ soil layer from nine farms and were used to calculate the annual rate of SOCC variation. The most recent SOCC measured in plots where land use change occurred 20 years ago was compared with the SOCC measured in areas of native vegetation (Cerrado). Results showed that (i) irrigated sandy agricultural lands replenished SOCC to the level observed in native vegetation by 20 years after a land use change event and are still capturing carbon at a significant rate, (ii) clayey, rainfed agricultural lands also sequester carbon, but these soils are not representative of the region, and (iii) sandy, rainfed agricultural lands, the predominant soil type and management practice in Western Bahia, are not a sink of $\mathrm{CO}_{2}$.
\end{abstract}

Keywords: soil carbon; sandy soils; Western Bahia; land use change

\section{Introduction}

Global soils play an important role in the global carbon (C) cycle, since they have about $1500 \mathrm{Pg}$ of organic carbon stored to a depth of one meter, representing the largest stock of this element on land [1-3]. This amount is twice as large as the atmospheric carbon pool and 2.5 times greater than that found in living organisms [4]. Changes that affect carbon balance in the soil can alter the carbon content stored in this compartment and substantially contribute to the net balance of $\mathrm{CO}_{2}$, as well as affect food security [5].

Land use change and agriculture have had an impact on this carbon reservoir and have been responsible for the emission of $148 \mathrm{Pg} \mathrm{C}$ from 1870 to 2014 [6]. This is considered the second-largest source of greenhouse gases to the atmosphere and is responsible for $24 \%$ of cumulative emissions $[7,8]$.

In Brazil-an agricultural country whose economic model is oriented towards commodity exports-land use change and agriculture together represent the main source of $\mathrm{CO}_{2}$ emissions to the atmosphere [9]. After the agricultural frontier expanded to the acidic, clayey soils of the Cerrado (Brazilian tropical savanna) in the central part of the country [10], the next most recent large agricultural frontier was established in the region called MATOPIBA, which includes the Cerrado biome in the states of Maranhão, Tocantins, Piauí, and Bahia [11].

MATOPIBA encompasses 73 million hectares, situated in areas where land is less expensive and where topography and climate have favored the development of regional agriculture [12,13]. 
Western Bahia is a notable region in MATOPIBA for its high yields of cotton, soybean, and maize [11]. Its soils are predominantly sandy and highly weathered, with low natural fertility, high porosity, and low water retention, but the use of technology has allowed record yields to be achieved in both rainfed and irrigated areas where a mixed system consisting of conventional and reduced tillage is applied $[11,14,15]$.

Maintaining and increasing carbon stocks, especially in these fragile soils, is essential for improving soil aggregation, increasing the cation exchange capacity (CEC), and water retention [11]. These changes are responsible for improving soil quality and increasing the resilience of the agricultural system in the face of extreme weather events (long dry spells), favoring higher yield, and assisting in atmospheric $\mathrm{CO}_{2}$ sequestration [16,17]. On the other hand, the sandy soil texture, high temperature, limited rainfall, and periodic disturbances to which the soils are submitted through tillage facilitate the decomposition and mineralization of organic matter $[9,11,18]$.

Studies that evaluate the impacts of management practices on carbon content in Brazilian soils have concentrated on soils in previously established agricultural regions, such as the clayey soils of the Cerrado of central Brazil and the Amazon [19-21]. In Western Bahia, an area experiencing considerable agricultural expansion, there are few studies [22,23]. Here, we evaluate whether the rainfed and irrigated agriculture systems in this region have been effective in restoring soil organic carbon content (SOCC) after land use change.

\section{Materials and Methods}

\subsection{Study Location}

The study area is part of the municipality of São Desidério (Figure 1) in Western Bahia, with a total of 600,000 hectares planted with crops [14]. São Desidério is currently the largest cotton producer in Brazil [15], and it is also notable for its soybean production [13].

According to the Köppen classification system, the climate of this region is type Aw (tropical seasonal climate with dry winters), with a mean annual temperature of $24{ }^{\circ} \mathrm{C}$ and a mean annual rainfall of $1145 \mathrm{~mm}$. Its topography is characterized by flat lands with a mean elevation of $778 \mathrm{~m}$, and there is a predominance of Arenosols and Oxisols with sandy granulometry and medium texture that are well developed, with low natural fertility, good permeability, and high porosity-factors that favor the implementation of large-scale, highly mechanized agriculture in these areas [13,24].

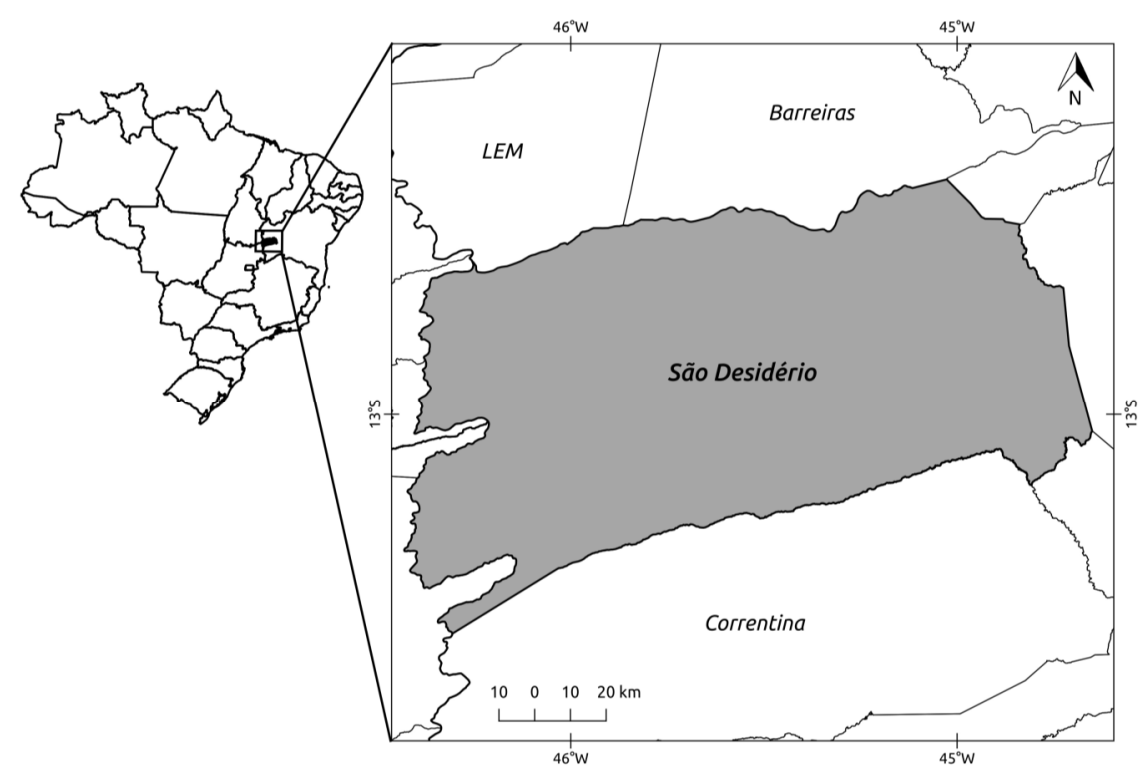

Figure 1. Location of the study area. LEM is the municipality of Luís Eduardo Magalhães. 


\subsection{Soil Sampling}

The data used in this study were provided by farmers who practice precision agriculture in São Desidério. The cropping system typically adopted in the region is a mixed-management system, in which reduced tillage is used for three years and in the fourth year, the soils are tilled [15]. The soils under study predominantly have high sand content, low CEC, and low organic carbon content (Table 1). The aim of soil sampling, a priori, was to guide the correction of soil fertility, and it was performed in intervals that ranged between two and four years. Such samples are generally collected just before tilling, to aid in the decision of how much fertilizer needs to be applied. A total of 5469 disturbed soil samples were collected from the $0.00-0.20 \mathrm{~m}$ soil layer over nine years (2010-2018) on nine farms, two of which use irrigated agriculture and seven that practice rainfed agriculture. Soil textures included sandy clay $\left(355 \mathrm{~g} \mathrm{~kg}^{-1}<\right.$ clay $<460 \mathrm{~g} \mathrm{~kg}^{-1} ; 15 \%$ of the samples), sandy clay loam $\left(200 \mathrm{~g} \mathrm{~kg}^{-1}<\right.$ clay $<301 \mathrm{~g} \mathrm{~kg}^{-1}$; $63 \%$ of the samples), and sandy loam $\left(167 \mathrm{~g} \mathrm{~kg}^{-1}<\right.$ clay $<196 \mathrm{~g} \mathrm{~kg}^{-1} ; 22 \%$ of the samples). The irrigated soils typically had clay content $<250 \mathrm{~g} \mathrm{~kg}^{-1}$, and only one center pivot plot had clay content of $290 \mathrm{~g} \mathrm{~kg}^{-1}$.

Soil samples within the same farm were taken from plots with similar physical and chemical characteristics, and the number of points sampled per year in each plot ranged from 3 to 95 . Sampling was not performed every year, and each plot was sampled between two and four times during the period of study. In addition, 40 soil samples were also collected in 2019 from the $0.00-0.20 \mathrm{~m}$ layer in areas of native vegetation preservation at six farms. The number of samples collected on each farm ranged from six to eight, and they had similar clay content to soils observed on the agricultural plots. These samples were used as controls, under the assumption that they are representative of the natural vegetation carbon content before the land was cleared for agriculture (over 20 years ago in all plots), and also assuming that the natural vegetation had been in equilibrium since the land use change happened.

The study used the following experimental design:

(i) Each plot is a continuous area within a single farm that has fairly uniform topography and uses a single management system. Plots may have 100 ha or more, in irrigated plots, the area irrigated by a single center pivot (typically $120 \mathrm{ha}$ ) is considered an experimental plot. The data collected within each plot were considered to be replicates.

(ii) We only considered plots that had data collected in two or more years. Data were paired according to the plot, allowing us to compute the rate of change of carbon content over time $(\Delta C / \Delta t$; Equation (1)).

(iii) To evaluate the effect of management practices, the data were divided into two groups: rainfed agriculture and irrigated agriculture.

(iv) In rainfed areas, the effect of the clay content on soil carbon accumulation was also evaluated. For this analysis, soils were separated in two classes with different clay contents $\left(\leq 250 \mathrm{~g} \mathrm{~kg}^{-1}\right.$ and $>250 \mathrm{~g} \mathrm{~kg}^{-1}$ ).

Crops grown in the rainfed system are mostly cotton, whereas in the irrigated areas, soy is typically rotated with cotton, with the occasional use of maize as a second crop. 
Table 1. Average chemical and physical properties of the nine farms.

\begin{tabular}{|c|c|c|c|c|c|c|c|c|c|c|c|c|c|c|}
\hline Farm & Management & $\mathrm{pH}\left(\mathrm{CaCl}_{2}\right)^{(1)}$ & $\mathrm{Ca}^{2+(2)}$ & $\mathrm{Mg}^{2+(2)}$ & $\mathrm{K}^{+(2)}$ & CEC $^{(3)}$ & P-Resin ${ }^{(4)}$ & SOCC $^{(5)}$ & Sand ${ }^{(6)}$ & Silt $^{(6)}$ & Clay $^{(6)}$ & $n$ & $\begin{array}{l}\text { Cerrado } \\
\text { SOCC }^{(5)}\end{array}$ & $\mathrm{T}$ \\
\hline & & & & \multicolumn{2}{|c|}{$-\mathrm{cmol}_{\mathrm{c}} \mathrm{dm}^{-3}$} & & $\mathrm{mg} \mathrm{dm}^{-3}$ & $\mathrm{~g} \mathrm{dm}^{-3}$ & \multicolumn{3}{|c|}{$-\mathrm{g} \mathrm{kg}^{-1}-$} & & $\mathrm{g} \mathrm{dm}^{-3}$ & years \\
\hline F1 & Rainfed & $5.84 \pm 0.06$ & $1.97 \pm 0.07$ & $0.67 \pm 0.02$ & $0.18 \pm 0.01$ & $4.24 \pm 0.10$ & $55.67 \pm 3.61$ & $9.73 \pm 1.32$ & nd & nd & nd & 73 & $11.79 \pm 0.98$ & 20 \\
\hline F2 & Rainfed & $5.59 \pm 0.02$ & $2.23 \pm 0.03$ & $0.76 \pm 0.01$ & $0.15 \pm 0.00$ & $4.76 \pm 0.04$ & $43.15 \pm 1.12$ & $8.93 \pm 0.22$ & $769 \pm 5$ & $15 \pm 1$ & $216 \pm 5$ & 140 & $10.24 \pm 1.18$ & 20 \\
\hline F3 & Rainfed & $5.79 \pm 0.10$ & $1.97 \pm 0.05$ & $0.88 \pm 0.04$ & $0.15 \pm 0.00$ & $4.70 \pm 0.10$ & $47.80 \pm 1.52$ & $9.17 \pm 0.57$ & $765 \pm 6$ & $22 \pm 3$ & $213 \pm 5$ & 37 & $12.73 \pm 1.31$ & 20 \\
\hline F4 & Rainfed & $5.79 \pm 0.02$ & $1.81 \pm 0.03$ & $0.58 \pm 0.01$ & $0.10 \pm 0.01$ & $4.02 \pm 0.05$ & $41.23 \pm 1.83$ & $7.36 \pm 0.32$ & $754 \pm 1$ & $19 \pm 3$ & $227 \pm 12$ & 66 & $13.43 \pm 2.28$ & 20 \\
\hline F5 & Rainfed & $5.53 \pm 0.04$ & $2.28 \pm 0.06$ & $0.74 \pm 0.03$ & $0.23 \pm 0.01$ & $5.02 \pm 0.10$ & $36.31 \pm 1.97$ & $13.18 \pm 0.65$ & $738 \pm 15$ & $21 \pm 4$ & $240 \pm 15$ & 33 & nd & nd \\
\hline F6 & Rainfed & $5.05 \pm 0.04$ & $2.71 \pm 0.06$ & $1.07 \pm 0.03$ & $0.23 \pm 0.01$ & $6.95 \pm 0.07$ & $46.08 \pm 2.29$ & $12.59 \pm 0.29$ & $612 \pm 36$ & $15 \pm 2$ & $373 \pm 37$ & 137 & $16.22 \pm 1.99$ & 20 \\
\hline F7 & Rainfed & $5.11 \pm 0.02$ & $1.91 \pm 0.03$ & $0.64 \pm 0.02$ & $0.20 \pm 0.00$ & $4.57 \pm 0.06$ & $29.95 \pm 1.41$ & $11.49 \pm 0.40$ & $787 \pm 4$ & $14 \pm 1$ & $198 \pm 3$ & 42 & nd & 25 \\
\hline F8 & Irrigated & $5.16 \pm 0.02$ & $2.07 \pm 0.03$ & $0.61 \pm 0.02$ & $0.17 \pm 0.00$ & $5.40 \pm 0.08$ & $48.12 \pm 1.40$ & $13.85 \pm 0.33$ & $762 \pm 7$ & $14 \pm 1$ & $224 \pm 7$ & 95 & $13.91 \pm 1.74$ & 20 \\
\hline F9 & Irrigated & $5.24 \pm 0.05$ & $1.77 \pm 0.06$ & $0.74 \pm 0.03$ & $0.21 \pm 0.01$ & $4.59 \pm 0.09$ & $32.92 \pm 2.95$ & $15.08 \pm 0.57$ & $761 \pm 8$ & $18 \pm 3$ & $221 \pm 8$ & 34 & nd & 25 \\
\hline
\end{tabular}

(1) $\mathrm{pH}$ in $\mathrm{CaCl}_{2} 0.01 \mathrm{~mol} \mathrm{~L}^{-1}$ (1.2.5 soil:solution). (2) Extracted with $\mathrm{KCl} 1 \mathrm{~mol} \mathrm{~L}^{-1}$. (3) Cation exchange capacity. (4) Available phosphorus by ion exchange resin. (5) Soil organic carbon content by the Walkley-Black method. ${ }^{(6)}$ Particle size by the pipette method. Mean value $\pm 95 \%$ confidence level. nd: not determined. T: time since land use changed from Cerrado vegetation to agriculture (years). $n$ : the number of soil samples collected in the most recent sampling from each farm (2016 for F3 and F4; 2017 for F1, F5, and F8; 2018 for F2, F6, F7, and F9). The samples from the Cerrado were collected in 2019 in preserved areas located in F1 $(n=6), \mathrm{F} 2(n=7), \mathrm{F} 3(n=7), \mathrm{F} 4(n=6), \mathrm{F} 6(n=8)$, and F8 $(n=6)$. 


\subsection{Physical-Chemical Analyses}

Particle size of the soil samples was determined using the pipette method, and organic carbon content was determined using the Walkley-Black method

Given the large number of samples and considering that the aim of sampling was to guide the correction of soil fertility, soil organic carbon content (SOCC) was measured based on volume (scooping soil samples) and the determination of carbon was performed through colorimetry. Although the use of measuring spoons may be imprecise and may underestimate the SOCC, these effects tend to be lower in soils with low organic matter content [25], such as those in this study. Moreover, for the sake of the statistical analysis, the imprecision (interpreted as large data variability) is offset by the large number of samples.

\subsection{Annual Carbon Variation Rate}

The annual rate of variation in organic carbon content, $\Delta C / \Delta t\left(\mathrm{~g} \mathrm{dm}^{-3} \mathrm{year}^{-1}\right)$, was calculated based on multiple measurements of SOCC obtained for the same plot over time (Equation (1)) to evaluate if the plot is contributing to the emission or sequestration of carbon:

$$
\Delta C / \Delta t=\left(\mathrm{Ct}_{\mathrm{f}}-\mathrm{Ct} \mathrm{t}_{\mathrm{o}}\right) /\left(\text { Year }_{\text {final }}-\text { Year }_{\text {initial }}\right),
$$

in which $\mathrm{Ct}_{\mathrm{f}}$ is the carbon content at the end of the period $\left(\mathrm{g} \mathrm{dm}^{-3}\right)$, and $\mathrm{Ct}_{\mathrm{o}}$ is the carbon content at the beginning of the period $\left(\mathrm{g} \mathrm{dm}^{-3}\right)$. Only plots with three or more replicates sampled in a given year were used to compute $\Delta C / \Delta t$. We obtained 109 values for the rate of carbon variation; however, after application of a bootstrap resampling technique over the time series, this value increased to 143 , of which 126 represented rainfed areas and 17 represented irrigated areas. We only bootstrapped data of plots that had three or four samples throughout the time. For example, if a plot had samples collected in 2011, 2015, and 2017, we performed the $\Delta C / \Delta t$ calculations for the period of 2011 to 2015, 2011 to 2017, and 2015 to 2017.

\subsection{Statistical Analysis}

The mean values and the confidence intervals of the data collected for each treatment are presented. Data normality was tested by both the Shapiro-Wilk and Kolmogorov-Smirnov tests. For normally distributed data, the mean values of the treatments were compared using Student's $t$-test, and for data that did not pass the Shapiro-Wilk test, the non-parametric Mann-Whitney test was used.

\section{Results}

\subsection{Data Normality}

Only data from irrigated agricultural plots are normally distributed according to both the Shapiro-Wilk and Kolmogorov-Smirnov tests $(p>0.05)$. The rainfed agricultural plot data fit the normal curve only according to the Kolmogorov-Smirnov test $(p>0.05)$, but not according to the Shapiro-Wilk test.

Although both datasets fit a normal distribution according to the Kolmogorov-Smirnov test, this test is less robust than the Shapiro-Wilk test [26]. Therefore, to test whether the management practices (irrigated and rainfed) and the clay content had an impact on the rate of soil carbon accumulation or emission, the parametric Student's $t$-test and the non-parametric Mann-Whitney test were used to compare the means and medians respectively, of the two treatments. The results obtained for both tests converged (next section, Tables 2 and 3), and therefore, the discussion will be based only on the results of the Student's $t$-test. 


\subsection{Effect of Management Practices and Clay Content on Soil Carbon Accumulation Rates}

The distribution of the rates of variation of the SOCC according to clay content for the irrigated and rainfed management systems of the nine farms is presented in Figure 2. The irrigated areas had soils with sandy clay loam texture $\left(200 \mathrm{~g} \mathrm{~kg}^{-1}<\right.$ clay $\left.<301 \mathrm{~g} \mathrm{~kg}^{-1}\right)$ and the variation in change of SOCC in these areas was predominantly positive ( $p=0.0659$; Table 2$)$, i.e., in spite of the coarse soil particle size, $\mathrm{C}$ accumulated in the soil at an average rate of $0.28 \mathrm{~g} \mathrm{C} \mathrm{dm}^{-3} \mathrm{year}^{-1}$ (Table 2). This annual rate represents a mean increase of $2.6 \%$ in SOCC in the $0.00-0.20 \mathrm{~m}$ layer (a volume-based calculation) (Table 4), a value 6.5 times greater than the goal of $0.4 \%$ a year (a mass-based estimate) established by the "4 per 1000: Soils for Food Security and Climate Initiative" (the 4:1000 Initiative) [27]. We stress here that this comparison between volume-based rates and mass-based rates is only valid if there are no changes in soil bulk density.

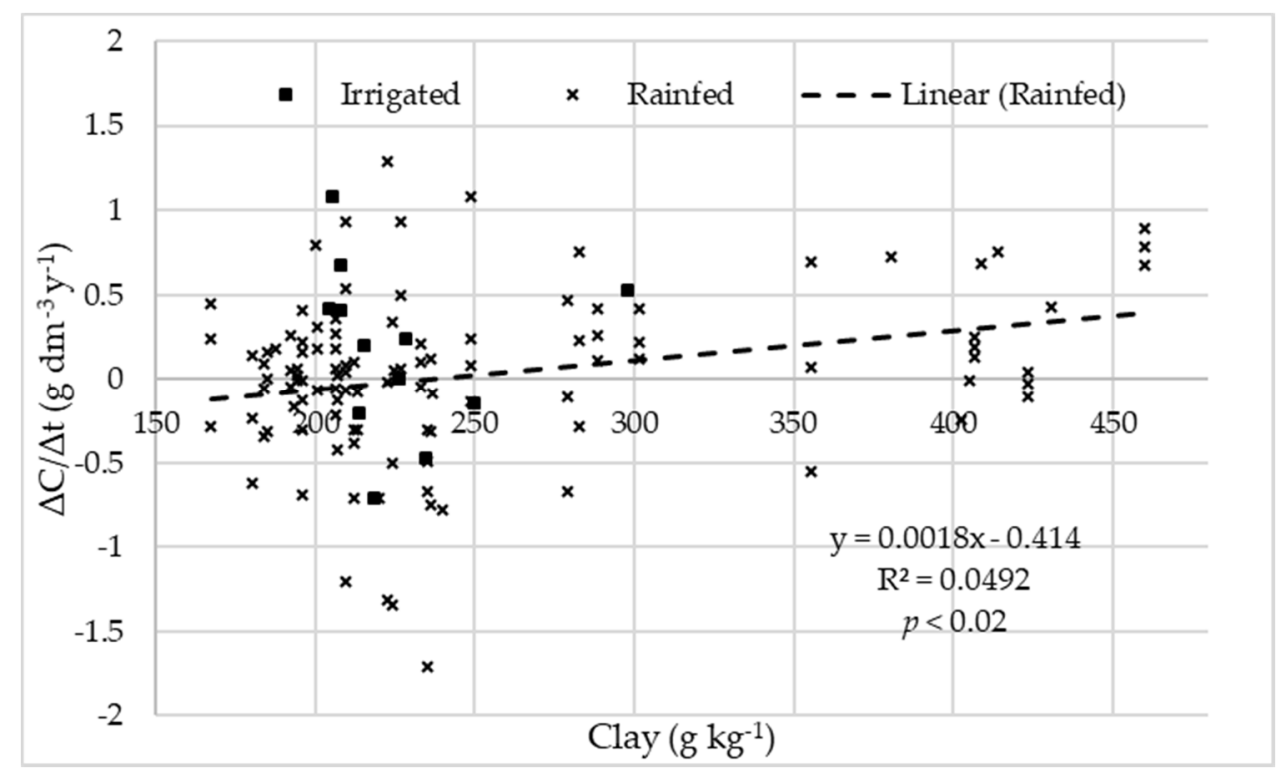

Figure 2. Annual rates of variation of carbon content in the $0.00-0.20 \mathrm{~m}$ layer obtained for the irrigated and rainfed agricultural plots according to clay content. The linear regression was calculated only for the rainfed plots.

The mean rate of $C$ accumulation in irrigated sandy agricultural lands was predominantly greater $(p=0.0856$; Table 2) than that observed in areas with rainfed agriculture. Temporal variation of $C$ in rainfed areas was $0.00 \pm 0.18 \mathrm{~g} \mathrm{C} \mathrm{dm}^{-3}$ year $^{-1}(p=0.4954$; Table 2).

Table 2. Results of Student's $t$-test and the Mann-Whitney test obtained for the $\Delta C / \Delta t$ values of irrigated and rainfed areas in the $0.00-0.20 \mathrm{~m}$ soil layer.

\begin{tabular}{|c|c|c|c|c|c|}
\hline \multirow{2}{*}{ Hypothesis } & \multicolumn{3}{|c|}{ Student's $t$-Test } & \multirow{2}{*}{$\begin{array}{c}\text { Mann-Whitney Test } \\
p \text {-Value }\end{array}$} & \multirow{2}{*}{$n$} \\
\hline & Mean & CI & $p$-Value & & \\
\hline \multicolumn{6}{|c|}{$\mathrm{g} \mathrm{C} \mathrm{dm}^{-3}$ year $^{-1}$} \\
\hline$\Delta C / \Delta t_{\text {irrigated }}>0$ & 0.28 & 0.38 & 0.0659 & 0.0574 & 17 \\
\hline$\Delta C / \Delta t_{\text {rainfed }}>0$ & 0.00 & 0.18 & 0.4954 & 0.3227 & 126 \\
\hline $\begin{array}{c}\Delta C / \Delta t_{\text {irrigated }}> \\
\Delta C / \Delta t_{\text {rainfed }}\end{array}$ & - & - & 0.0856 & 0.0798 & 143 \\
\hline
\end{tabular}


Rainfed agriculture occupies areas with wide variation in clay content $\left(167-430 \mathrm{~g} \mathrm{~kg}^{-1}\right.$; Figure 1). Clayey soils make it possible to increase and conserve organic carbon over time by favoring the occurrence of the two main factors that coordinate these processes: physical protection and formation of organo-mineral complexes through adsorption of organic matter on the surface of minerals [28]. Thus, we also tested whether variation in $C$ content in rainfed areas differed between less clayey soils (167 to $250 \mathrm{~g} \mathrm{~kg}^{-1}$ ) and more clayey soils (250 to $430 \mathrm{~g} \mathrm{~kg}^{-1}$ ) (Table 3).

The sandier rainfed areas had negative $\Delta C / \Delta t$ on average and are a non-significant source of carbon to the atmosphere ( $p=0.7734$; Table 3$)$. In contrast, the observed $\Delta C / \Delta t$ in more clayey areas was significantly greater than zero $(p<0.01$; Table 3$)$, and there is sequestration of $C$ at a mean rate of $0.42 \mathrm{~g} \mathrm{C} \mathrm{dm}^{-3}$ year $^{-1}$. This rate corresponds to an annual increase of $3.0 \%$ in $C$ content in the $0.00-0.20 \mathrm{~m}$ layer and is 7.6 times greater than the value established by the 4:1000 Initiative (Table 4).

In addition, a linear regression of the carbon content change rate against soil texture was significant at $p<0.02$ (Figure 2), indicating that $\Delta C / \Delta t$ increases by $0.18 \mathrm{~g} \mathrm{C} \mathrm{dm}^{-3}$ year $^{-1}$ for each $10 \%$ increase in soil clay content.

Table 3. Results of Student's $t$-test and the Mann-Whitney test obtained for the $\Delta C / \Delta t$ values of rainfed areas with different clay contents in the $0.00-0.20 \mathrm{~m}$ soil layer.

\begin{tabular}{|c|c|c|c|c|c|}
\hline \multirow{2}{*}{ Hypothesis } & \multicolumn{3}{|c|}{ Student's $t$-Test } & \multirow{2}{*}{$\frac{\text { Mann-Whitney Test }}{p \text {-Value }}$} & \multirow{2}{*}{$n$} \\
\hline & Mean & CI & $p$-Value & & \\
\hline \multicolumn{5}{|c|}{$\mathrm{g} \mathrm{C} \mathrm{dm}^{-3}$ year $^{-1}$} & \\
\hline$\Delta C / \Delta t_{167<x<250}>0$ & -0.09 & 0.25 & 0.7734 & 0.748 & 76 \\
\hline$\Delta C / \Delta t_{250<x<430}>0$ & 0.42 & 0.26 & 0.0011 & 0.001 & 26 \\
\hline $\begin{array}{c}\Delta C / \Delta t_{250<x<430}> \\
\Delta C / \Delta t_{167<x<250}\end{array}$ & - & - & 0.0023 & 0.001 & 102 \\
\hline
\end{tabular}

$n$ : number of $\Delta C / \Delta t$ values evaluated. CI: $95 \%$ confidence level.

Table 4. Percentage of annual variation of the carbon content in the areas evaluated and their comparison with the goal established by the 4:1000 Initiative.

\begin{tabular}{ccccc}
\hline $\begin{array}{c}\text { Management Type and } \\
\text { Particle Size }\end{array}$ & $\begin{array}{c}\text { Annual Variation } \\
\text { in C Content }\end{array}$ & $\begin{array}{c}\text { Goal of the 4:1000 } \\
\text { Initiative }\end{array}$ & $\begin{array}{c}\text { Comparison of the } \\
\text { Measurements with the } \\
\text { Goal of the 4:1000 Initiative }\end{array}$ & $n$ \\
\hline \multicolumn{2}{c}{$\%$ year $^{-1}$} & & \\
\hline Irrigated & $2.60 \pm 5.85$ & & 6.5 times more & 17 \\
Rainfed & $0.73 \pm 10.54$ & 0.40 & 2.4 times more & 131 \\
Rainfed $\left(<250 \mathrm{~g} \mathrm{~kg}^{-1}\right.$ clay) & $-0.57 \pm 8.99$ & & 7.6 times more & 76 \\
Rainfed $\left(>250 \mathrm{~g} \mathrm{~kg}^{-1}\right.$ clay) & $3.03 \pm 5.57$ & & & 26 \\
\hline
\end{tabular}

$n$ : number of $\Delta C / \Delta t$ values evaluated.

In irrigated sandy areas that have been cultivated for more than 20 years, the SOCC was not different from that of the native Cerrado $(p<0.05)$, i.e., the management practices used in those areas allowed for the replenishment of the original SOCC (Table 5). In contrast, the rainfed areas had lower SOCC than those of the Cerrado measurements $(p<0.05)$, and the areas with the greatest decreases were those with sandy soils, with a reduction of $26 \%$ in the SOCC relative to native vegetation. This indicates that even after 20 years, this management practice was not able to restore the carbon content to what it was before land use change. 
Table 5. Comparison of soil organic carbon content (SOCC) in the $0.00-0.20 \mathrm{~m}$ layer in areas of native Cerrado and in areas cultivated for more than 20 years under different management practices and with different soil particle sizes.

\begin{tabular}{ccccc}
\hline \multirow{2}{*}{ Management } & Land Use & \multicolumn{2}{c}{ SOCC } & \multirow{2}{*}{$\boldsymbol{n}$} \\
\cline { 3 - 4 } & & $\mathbf{g ~ d m}^{-3}$ & \% Change & \\
\hline \multirow{2}{*}{ Rainfed } & Cerrado & $13.00 \pm 0.94 \mathrm{a}$ & & 34 \\
& Cultivated area & $8.99 \pm 0.19 \mathrm{~b}$ & -30.8 & 394 \\
\hline \multirow{2}{*}{ Irrigated $_{\text {sandy }}$} & Cerrado & $13.91 \pm 2.14 \mathrm{a}$ & & 6 \\
& Cultivated area & $13.85 \pm 0.33 \mathrm{a}$ & $\approx 0$ & 95 \\
\hline \multirow{2}{*}{ Rainfed $_{\text {clayey }}$} & Cerrado & $16.22 \pm 1.98 \mathrm{a}$ & & 8 \\
& Cultivated area & $12.45 \pm 0.75 \mathrm{~b}$ & -23.2 & 36 \\
\hline \multirow{2}{*}{ Rainfed $_{\text {sandy }}$} & Cerrado & $11.71 \pm 1.05 \mathrm{a}$ & & 26 \\
& Cultivated area & $8.66 \pm 0.16 \mathrm{~b}$ & -26.0 & 358 \\
\hline
\end{tabular}

Mean value $\pm 95 \%$ confidence level. Mean values followed by different letters in the column differed significantly $(p<0.05)$ from each other according to the Student's $t$-test.

\section{Discussion}

The soils of Western Bahia are on sandstone formations of the Urucuia Group and contain sandy clay and sandy material originating from the Vazante formation [22,29-31]. These soils are fragile and not very resilient due to their predominantly sandy texture, susceptibility to erosion, low natural fertility, and low water-retaining capacity [11,32]. The low specific surface area, presence of charges, and capacity for forming aggregates limits the capacity for physical protection and the formation of organo-mineral complexes that assist in stabilization of organic matter in the soil [33]. In addition, the seasonal rainfall regime and high temperatures limit biomass production and favor mineralization of the organic matter that enters the system [32], representing an additional limitation to the accumulation and maintenance of carbon in these soils. This limitation is less critical in the irrigated fields, which are not limited by water and have higher net primary production (NPP) than the rainfed crops because they have two growing seasons in a year. As the crops grown are typically cotton and soy, which have similar biomass, we attribute the higher carbon accumulation in irrigated areas to double cropping, not to the choice of crop grown.

In spite of these unfavorable conditions, highly mechanized irrigated agriculture in sandy clay loam soils of this region allowed the amount of carbon lost after land use change to be regenerated in the $0.00-0.20 \mathrm{~m}$ layer after 20 years of cultivation. Although they reached a SOCC similar to that of the native Cerrado, these areas maintain a rate of increase of $0.28 \mathrm{~g} \mathrm{C} \mathrm{dm}^{-3}$ year $^{-1}$, indicating that the carbon content may in the future exceed that observed in the native vegetation area. Our results agree with a study comparing different land uses in Western Bahia, in which the authors found that irrigated areas contained higher carbon stocks $\left(45.5 \mathrm{Mg} \mathrm{C} \mathrm{ha}^{-1}\right)$ than those of the native Cerrado (40.1 Mg C ha-1) in the $0.00-0.30 \mathrm{~m}$ layer, confirming that this management practice can sequester carbon in these soils [21].

Reduced tillage in Arenosols in irrigated areas in Northeast Brazil with perennial crops led to a $\mathrm{C}$ accumulation rate of $1.39 \mathrm{Mg} \mathrm{C} \mathrm{ha}^{-1}$ year $^{-1}$ in the $0.00-0.20 \mathrm{~m}$ layer and increased the total $\mathrm{C}$ content in the layer by $25 \%$ compared to the same layer under native Cattinga vegetation (xeric shrubland) [32]. The greater rate of SOCC accumulation observed in this study may be associated with the no-tillage practices in these areas-soil that is not turned over avoids breaking up aggregates and exposure of the organic matter to microbial oxidation [34].

Water availability, which was ensured by irrigation, and precision agriculture practices, such as addition of nutrients through fertilization, increased yield and the contributions of shoot and root biomass that make up soil organic matter [19,35]. In spite of the high temperatures observed in the region - a factor that activates microbial activity and accelerates the decomposition rate-this set 
of actions allowed primary production of biomass to exceed the biomass decomposition rate and, therefore, favor carbon sequestration [36].

The annual increase of $2.6 \%$ in SOCC in irrigated sandy areas is 6.5 times greater than the $0.4 \%$ proposed by the 4:1000 Initiative to assist in neutralization of $\mathrm{CO}_{2}$ emissions. This result is also in agreement with a study performed in irrigated areas in a semi-arid region, where an annual increase of $6.3 \%$ in carbon content was found [37]. Although these accumulation rates are high, they can be explained by two factors. First, the original soil had a low SOCC (Table 1), and much of it was probably lost during clearing. Second, the natural vegetation NPP is much lower than the NPP of the replacement vegetation—highly productive crops—especially if irrigated [38].

The irrigated area in Western Bahia increased 150 times over a 30-year period, with a total of 190,000 hectares in 2018, which represents approximately $6 \%$ of the agricultural area of the region [39]. Therefore, based on the SOCC accumulation rate observed in this study, we estimate that the potential for carbon sequestration in the $0.00-0.20 \mathrm{~m}$ soil layer in irrigated areas of this region is roughly $69 \mathrm{Gg} \mathrm{C}$ year $^{-1}$. However, this value is only a rough estimate, since the determination of organic matter was performed on a volumetric basis and did not include the effects of possible variations in soil bulk density.

Despite these results, more thorough studies need to be conducted, in particular to investigate $C$ storage in deeper layers, which are less sensitive to soil tilling practices. In addition, most of the carbon in the upper soil layers experiences a high rate of mineralization [5], and it is probable that, given the regional conditions (sandy soils, high temperatures, and limited water availability), this gain in SOCC may be easily reversible through mineralization if irrigation and the application of other inputs cease [17]. In rainfed areas, it is estimated that the half-life of carbon in sandy soils of Western Bahia subject to conventional tillage is 2.16-2.31 years [22]; however, there is no similar information for irrigated areas of the region.

Furthermore, although there is the possibility of carbon sequestration in this region through the use of irrigation, this result must be interpreted cautiously, since recent studies indicate the possibility of future socio-environmental conflicts arising from unplanned use of water resources in Western Bahia [39]. Expansion of the arable area at the expense of native vegetation and combined with inadequate management increases surface runoff and reduces recharging of aquifers [39-41].

Unlike the irrigated sandy areas, the rainfed agricultural areas had wide variation in clay content $\left(167-430 \mathrm{~g} \mathrm{~kg}^{-1}\right)$. In more sandy areas (167-250 $\mathrm{g} \mathrm{kg}^{-1}$ of clay), there was a non-significant source of carbon to the atmosphere from the $0.00-0.20 \mathrm{~m}$ layer; in contrast, the most clayey soils (250-430 $\mathrm{g} \mathrm{kg}^{-1}$ of clay) sequestered $0.42 \mathrm{~g} \mathrm{C} \mathrm{dm}^{-3}$ year $^{-1}\left(0.84 \mathrm{Mg} \mathrm{C} \mathrm{ha}^{-1}\right.$ year-1) (Table 3). These values are near the annual $\mathrm{C}$ loss and accumulation rates in the soil, which can range from 0.1 to $10 \mathrm{Mg} \mathrm{C}^{-1}$ year $^{-1}$ depending on the dominant process that acts on organic matter stabilization [28]. Since these study areas are under the same climate and management conditions, it is very likely $(p<0.01)$ that this difference in $C$ sequestration dynamics is a result of soil texture, as has been observed in other studies [22,28,42].

The rainfed areas with higher clay contents are storing an average of $0.84 \mathrm{MgC} \mathrm{ha}^{-1}$ year $^{-1}$, a rate $50 \%$ greater than that observed in irrigated sandy areas. This is due to the fact that the SOCC in the irrigated sandy areas has already reached the level found in the control areas (native Cerrado) (Table 5). Thus, the rates in the irrigated areas are expected to be lower, because the system is close to an equilibrium [5]. In fact, it was expected that the irrigated areas would have greater accumulation of SOCC and achieve equilibrium with the native Cerrado more rapidly, since rainfed agriculture, a priori, produces less shoot and root biomass due to water limitations [38].

In rainfed agriculture, the difference between the rates observed in the typically sandy and typically clayey areas is due to soil particle size. The content of organic matter in the soil is directly proportional to its content of clay and silt [43]. This is because the organic matter present in these fractions is less vulnerable to degradation than the organic matter of the sand fraction [44]. This fact underscores the importance of this soil characteristic for the accumulation and conservation of organic 
matter in the soil. Therefore, carbon storage in the soil does not depend only on biomass production, but on other factors as well, such as the capacity of the soil to stabilize the organic matter deposited on and in it [1]. In addition to the greater physical and chemical protection that clayey soils offer to organic matter, they also have greater water-retaining capacity, and thus they can minimize water stress on crops and increase biomass production, favoring greater SOCC accumulation in these soils [44].

The soils with the highest clay content in areas with rainfed management practices accumulated 7.6 times more carbon than the target amount proposed by the 4:1000 Initiative, and therefore they have potential for assisting in $\mathrm{CO}_{2}$ sequestration. In spite of this positive result, this finding cannot be extrapolated to all of Western Bahia, because these soils are not dominant in the region [45].

Conversely, the cultivated, rainfed areas on soils with sandy texture did not accumulate carbon. In contrast to our results, other authors have found that even soils with clay content above $300 \mathrm{~g} \mathrm{~kg}^{-1}$ act as a source of $C$ to the atmosphere in Western Bahia [22]. This difference in relation to our results may arise from the management practices adopted: in our study area, soils are normally turned over every four years, whereas in the study cited, soil turnover occurred annually, which highlights the relevance of management practices in carbon sequestration [46].

Our results indicate that only irrigated sandy areas were able to accrue the SOCC observed in native vegetation (Table 5). The choice of management practice, especially in fragile soils, determines whether the soil acts as a carbon sink and assists in mitigating the effects of climate change [37]. This is shown in a study that found that adoption of no-till was able to grow the carbon stock at a rate of 3.1 $\mathrm{Mg} \mathrm{C} \mathrm{ha}{ }^{-1}$ year $^{-1}$ in the sandy soils of the MATOPIBA region-a value 3.5 times greater than that observed in the present study [18].

Our results for the period of 2010-2018 are important for evaluating the regional context of sustainability and the contribution to climate change of precision agriculture in rainfed and irrigated areas in Western Bahia. Considering that more than $90 \%$ of the two million hectares of arable land of this region is rainfed [47] and has predominantly sandy soils [11,15,22,31], it can be inferred that, in general, the practice of agriculture that has developed in this new Brazilian agricultural frontier is acting as neither a source nor a sink of carbon.

In addition to the fragilities and limitations arising from the physical and chemical properties of these soils and from seasonal climate conditions, agricultural management practices may be contributing to a decline in carbon content in sandy, rainfed soils. The practice of farmers turning soil over every four years in the region [15] is recognized as favoring reduction in carbon stocks, particularly in rainfed areas [37]. After cycles of fallow followed by soil turnover, a decline in soil carbon can be observed [48]. In contrast, substituting conventional tillage systems with no-till systems has proven to be an effective alternative that helps sequester carbon in the soil $[28,49]$. The carbon content in no-till areas in Western Bahia was $3.8 \mathrm{Mg} \mathrm{C} \mathrm{ha}^{-1}$ greater than that in areas of conventional tillage [50].

Loss of carbon, especially in fragile soils of hot and dry regions, is incompatible with concepts of ecological intensification of agricultural areas, since it reduces soil quality and has an impact on yield and sustainability $[51,52]$. Some of the adverse effects of the carbon loss in the soil are reduction in water retention, lower CEC, limited capacity of vegetation to resist environmental stresses, lower biological activity and nutrient cycling, destruction of aggregates, and increased erosion [53].

Recent studies have been concerned with evaluation of management systems appropriate for these sandy soils that have been intensively cultivated in Western Bahia and cover $20 \%$ of MATOPIBA [11,18,23,50,54]. It is estimated that the half-life of carbon in these soils is 2.16 years when under conventional tillage [22]. This result suggests the need to adopt more efficient practices that provide conditions so that the biomass deposited is stabilized and remains in the edaphic environment.

Chemical adsorption on the surface of clay minerals and the physical protection provided by aggregates are essential mechanisms in this process of stabilization of SOCC. Since soil particle size is a static property, i.e., it changes only through the slow activity of weathering, efforts must focus on 
strategies that promote physical protection of the biomass that is introduced to the soil. Such strategies require management practices that reduce movement of this biomass and preserve the soil's aggregates.

\section{Conclusions}

This is the first study that uses a time series of organic carbon measurements in the soils of Western Bahia for the purpose of evaluating the impact of irrigated and rainfed management practices on the carbon content of the sandy soils of that region. The results led to three main conclusions: (i) irrigated sandy agricultural lands, 20 years after the land use change event, re-established SOCC to the level observed in the native vegetation and are still capturing carbon at a significant rate, (ii) clayey, rainfed agricultural lands also sequester carbon, but these soils are not representative of the region, and (iii) sandy, rainfed agricultural lands-the predominant soil type and management practice in Western Bahia-are not a sink of $\mathrm{CO}_{2}$.

Although irrigation has proven to be an effective management practice for sequestering carbon in these sandy soils, its use on a wide scale is subject to hydroclimatic evaluation to ensure regional water security. Furthermore, sandy soils, such as those that occur in Western Bahia, are typically not amenable to stabilization of the organic carbon introduced in them. Thus, the soil organic carbon that accumulates in irrigated sandy soils may decline rapidly due to mineralization if primary production ceases in the event of water and/or economic limitations that make it impossible to maintain irrigation.

Finally, despite uncertainties related to the short extent of the data time series and the method used to measure organic carbon, this study provides relevant results regarding the impact that agricultural intensification has had on this new agricultural frontier and may guide decision makers in formulation of public policies that favor large-scale carbon sequestration in the region.

Author Contributions: Experimental design, M.H.C.; formal analysis, R.C. and G.F.P.; writing-original draft preparation, R.C. and G.F.P.; writing—review and editing, M.H.C.; supervision, M.H.C.; project administration, M.H.C.; funding acquisition, M.H.C. All authors have read and agreed to the published version of the manuscript.

Funding: This research was funded by PRODEAGRO, grant number 039/2019.

Acknowledgments: We thank the farmers who provided the data used in this study. We keep their identities and the names and locations of their farms confidential.

Conflicts of Interest: The authors declare no conflict of interest. The funders had no role in the design of the study, in the collection, analyses, or interpretation of data; in the writing of the manuscript, or in the decision to publish the results.

\section{References}

1. Grüneberg, E.; Schöning, I.; Hessenmöller, D.; Schulze, E.-D.; Weisser, W.W. Organic layer and clay content control soil organic carbon stocks in density fractions of differently managed German beech forests. For. Ecol. Manag. 2013, 303, 1-10. [CrossRef]

2. Food and Agriculture Organization of the United Nations-FAO. Soil Organic Carbon: The Hidden Potential; FAO: Roma, Italy, 2017; p. 90. Available online: http://www.fao.org/3/a-i6937e.pdf (accessed on 12 September 2019).

3. Dintwe, K.; Okin, G.S. Soil organic carbon in savannas decreases with anthropogenic climate change. Geoderma 2018, 309, 7-16. [CrossRef]

4. Dash, P.K.; Bhattacharyya, P.; Roy, K.S.; Neogi, S.; Nayak, A.K. Environmental constraints' sensitivity of soil organic carbon decomposition to temperature, management practices and climate change. Ecol. Indic. 2019, 107, e105644. [CrossRef]

5. Schiefer, J.; Lair, G.J.; Lühgens, C.; Wild, E.M.; Steier, P.; Blum, W.E.H. The increase of soil organic carbon as proposed by the " $4 / 1000$ initiative" is strongly limited by the status of soil development-A case study along a substrate age gradient in Central Europe. Sci. Total Environ. 2018, 628-629, 840-847. [CrossRef] [PubMed]

6. Sá, J.C.M.; Lal, R.; Cerri, C.C.; Lorenz, K.; Hungria, M.; Carvalho, P.C.F. Low-carbon agriculture in South America to mitigate global climate change and advance food security. Environ. Int. 2017, 98, 102-112. [CrossRef]

7. Scharlemann, J.P.W.; Tanner, E.V.J.; Hiederer, R.; Kapos, V. Global soil carbon: Understanding and managing the largest terrestrial carbon pool. Carbon Manag. 2014, 5, 81-91. [CrossRef] 
8. Soussana, J.F.; Lutfalla, S.; Ehrhardt, F.; Rosenstock, T.; Lamanna, C.; Havlík, P.; Richards, M.; Wollenberg, E.L.; Chotte, J.L.; Torquebiau, E.; et al. Matching policy and science: Rationale for the ' 4 per 1000-soils for food security and climate' initiative. Soil Tillage Res. 2019, 188, 3-15. [CrossRef]

9. Don, A.; Schumacher, J.; Freibauer, A. Impact of tropical land-use change on soil organic carbon stocks-A meta-analysis. Glob. Chang. Biol. 2010, 17, 1658-1670. [CrossRef]

10. Delgado, G.C. Capital Financeiro e Agricultura no Brasil: 1965-1985; Ícone Unicamp: Campinas, Brazil, 1985; p. 240.

11. Donagemma, G.K.; Freitas, P.L.; Balieiro, F.C.; Fontana, A.; Spera, S.T.; Lumbreras, J.F.; Viana, J.H.M.; Araújo Filho, J.C.; Santos, F.C.; Albuquerque, M.R.; et al. Characterization, agricultural potential, and perspectives for the management of light soils in Brazil. Pesqui. Agropecu. Bras. 2016, 51, 1003-1020. [CrossRef]

12. Empresa Brasileira de Pesquisa Agropecuária-Embrapa. Aptidão Agrícola das Terras do Matopiba; Embrapa Solos: Rio de Janeiro, Brazil, 2015; p. 48.

13. Araújo, M.L.S.; Sano, E.E.; Bolfe, E.L.; Santos, J.R.N.; Santos, J.S.; Silva, F.B. Spatiotemporal dynamics of soybean crop in the Matopiba region, Brazil (1990-2015). Land Use Policy 2019, 80, 57-67. [CrossRef]

14. AIBA (Associação de Agricultores e Irrigantes da Bahia). Anuário da Safra do Oeste Baiano-Safra 2017-2018; Instituto Aiba: Barreiras, Brazil, 2019; p. 39. Available online: http://aiba.org.br/wp-content/uploads/2019/06/ Anu\%C3\%A1rio-2019-Portugu\%C3\%AAs-Digital.pdf (accessed on 17 September 2019).

15. Dionizio, E.; Costa, M.H. Influence of land use and land cover on hydraulic and physical soil properties at the Cerrado Agricultural Frontier. Agriculture 2019, 9, 24. [CrossRef]

16. Lal, R. Promoting "4 Per Thousand" and "Adapting African Agriculture" by south-south cooperation: Conservation agriculture and sustainable intensification. Soil Tillage Res. 2019, 188, 27-34. [CrossRef]

17. Keel, S.J.; Anken, T.; Büchi, L.; Chervet, A.; Fliessbach, A.; Flish, R.; Elie-Huguenin, O.; Mäder, P.; Mayer, J.; Sinaj, S.; et al. Loss of soil organic carbon in Swiss long-term agricultural experiments over a wide range of management practices. Agric. Ecosyst. Environ. 2019, 286, e106654. [CrossRef]

18. Gmach, M.R.; Dias, B.O.; Silva, C.A.; Nóbrega, J.C.A.; Lustosa-Filho, J.; Siqueira-Neto, M. Soil organic matter dynamics and land-use change on Oxisols in the Cerrado, Brazil. Geoderma Reg. 2018, 14, e00178. [CrossRef]

19. Silva, J.E.; Resck, D.V.S.; Corazza, E.J.; Vivaldi, L. Carbon storage in clayey Oxisol cultivated pastures in the “Cerrado" region, Brazil. Agric. Ecosyst. Environ. 2004, 103, 357-363. [CrossRef]

20. Rittl, T.F.; Oliveira, D.; Cerri, C.E.P. Soil carbon stock changes under different land uses in the Amazon. Geoderma Reg. 2017, 10, 138-143. [CrossRef]

21. Dias, F.P.M.; Hübner, R.; Nunes, F.J.; Leandro, W.M.; Xavier, F.A.Z. Effects of land-use change on chemical attributes of a Ferralsol in Brazilian Cerrado. Catena 2019, 177, 180-188. [CrossRef]

22. Silva, J.E.; Lemainski, J.; Resck, D.V.S. Perdas de matéria orgânica e suas relações com a capacidade de troca catiônica em solos da região de Cerrados do Oeste baiano. Rev. Bras. Cienc. Solo 1994, 18, 541-547.

23. Silva, E.A.D. Land Use Change, Soil Physical Properties and Carbon Stocks at a Sandy Soil Domain of a Cerrado Agriculture Frontier. Ph.D. Thesis, Viçosa Federal University, Viçosa, Brazil, 2019.

24. Passo, D.P.; Castro, K.B.; Martins, E.S.; Gomes, M.P.; Reatto, A.; Lima, L.A.S.; Carvalho Junior, O.A.; Gomes, R.A.T. Caracterização Geomorfológica do Município de São Desidério, BA, Escala 1:50.000-Boletim de Pesquisa e Desenvolvimento 283; Empresa Brasileira de Pesquisa Agropecuária: Distrito Federal, Brazil, 2010; p. 29. Available online: https://ainfo.cnptia.embrapa.br/digital/bitstream/item/75869/1/bolpd-283.pdf (accessed on 10 October 2019).

25. Sampaio, T.F.; Fernandes, D.M.; Guerrini, I.A.; Bogiani, J.C.; Backes, C. Comparação entre métodos para determinação de carbono orgânico em amostras de solo mensuradas por volume ou massa. Rev. Bras. Cienc. Solo 2012, 36, 517-523. [CrossRef]

26. Razali, N.M.; Wah, Y.B. Power comparisons of Shapiro-Wilk, Kolmogorov-Smirnov, Lilliefors and Anderson-Darling tests. J. Stat. Model Anal. 2011, 2, 21-33.

27. Minasny, B.; Malone, B.; McBratney, A.B.; Angers, D.A.; Arrouays, D.; Chambers, A.; Chaplot, V.; Chen, Z.S.; Cheng, K.; Das, B.S.; et al. Soil carbon 4 per mille. Geoderma 2017, 292, 59-86. [CrossRef]

28. Pinheiro, E.F.M.; Campos, D.V.L.; Balieiro, F.C.; Anjos, L.H.C.; Pereira, M.G. Tillage systems effects on soil carbon stock and physical fractions of soil organic matter. Agric. Syst. 2015, 132, 35-39. [CrossRef] 
29. Jacomine, P.K.T.; Cavalcanti, A.C.; Ribeiro, M.R.; Montenegro, J.O.; Burgos, N.; Mélo Filho, H.F.R.; Formiga, R.A. Levantamento Exploratório-Reconhecimento de solos da Margem Esquerda do Rio São Francisco Estado da Bahia-Boletim Técnico $n^{\circ}$ 38; Embrapa Solos: Recife, Brazil, 1976; p. 439. Available online: https://www.embrapa.br/solos/busca-de-publicacoes/-/publicacao/335789/levantamento-exploratorio--reconhecimento-de-solos-da-margem-esquerda-do-rio-sao-francisco-estado-da-bahia (accessed on 11 October 2019).

30. Jacomine, P.K.T.; Cavalcanti, A.C.; Silva, F.B.R.; Montenegro, J.O.; Formiga, R.A.; Burgos, N.; Mélo Filho, H.F.R. Levantamento Exploratório-Reconhecimento de solos da Margem Direita do Rio São Francisco Estado da Bahia. Embrapa Solos-Boletim Técnico $n^{\circ}$ 52; Embrapa Solos: Recife, Brazil, 1979; p. 773. Available online: https://www.embrapa.br/busca-de-publicacoes/-/publicacao/335822/levantamentoexploratorio---reconhecimento-de-solos-da-margem-direita-do-rio-sao-francisco-estado-da-bahia (accessed on 11 October 2019).

31. Freitas, P.L.; Bernardi, A.C.C.; Manzatto, C.V.; Ramos, D.P.; Dowich, I.; Landers, J.N. Comportamento Físico-Químico dos Solos de Textura Arenosa e Média do Oeste Baiano. Embrapa Solos. Comunicado Técnico $n^{\circ} 27$; Embrapa Solos: Rio de Janeiro, Brazil, 2014; p. 7. Available online: https://www.infoteca.cnptia.embrapa.br/ bitstream/doc/965477/1/comtec272004solosoestebaiano.pdf (accessed on 10 October 2019).

32. Santos, L.R.; Lima, A.M.N.; Cunha, J.C.; Rodrigues, M.S.; Soares, E.M.B.; Santos, L.P.A.; Silva, A.V.L.; Fontes, M.P.F. Does irrigated mango cultivation alter organic carbon stocks under fragile soils in semiarid climate? Sci. Hortic. 2019, 255, 121-127. [CrossRef]

33. Zinn, Y.L.; Lal, R.; Resck, D.V.S. Changes in soil organic carbon stocks under agriculture in Brazil. Soil Tillage Res. 2005, 84, 28-40. [CrossRef]

34. Schmidt, M.W.I.; Torn, M.S.; Abiven, S.; Dittmar, T.; Guggenberger, G.; Janssens, I.A.; Kleber, M.; Kögel-Knabner, I.; Lehmann, J.; Manning, D.A.C. Persistence of soil organic matter as an ecosystem property. Nature 2011, 478, 49-56. [CrossRef] [PubMed]

35. Kochsiek, A.E.; Knops, J.M.H.; Walters, D.T.; Arkebauer, T.J. Impacts of management on decomposition and the litter-carbon balance in irrigated and rainfed no-till agricultural systems. Agric. For. Meteorol. 2009, 149, 1983-1993. [CrossRef]

36. Xiong, X.; Grunwald, S.; Myers, D.B.; Ross, C.W.; Harris, W.G.; Comerford, N.B. Interaction effects of climate and land use/land cover change on soil organic carbon sequestration. Sci. Total Environ. 2014, 493, 974-982. [CrossRef]

37. Alidoust, E.; Afyuni, M.; Hajabbasi, M.A.; Mosaddghi, M.R. Soil carbon sequestration potential as affected by soil physical and climatic factors under different land uses in a semiarid region. Catena 2018, 171, 62-71. [CrossRef]

38. Zhou, X.; Zhou, L.; Nie, Y.; Fu, Y.; Du, Z.; Shao, J.; Zheng, Z.; Wang, X. Similar responses of soil carbon storage to drought and irrigation in terrestrial ecosystems but with contrasting mechanisms: A meta-analysis. Agric. Ecosyst. Environ. 2016, 228, 70-81. [CrossRef]

39. Pousa, R.; Costa, M.H.; Pimenta, F.M.; Fontes, V.C.; Brito, V.F.A.B.; Castro, M. Climate change and intense irrigation growth in Western Bahia, Brazil: The urgent need for hydroclimatic monitoring. Water 2019, 11, 933. [CrossRef]

40. Buller, L.S.; Bergier, I.; Ortega, E.; Moraes, A.; Bayma-Silva, G.; Zanetti, M.R. Soil improvement and mitigation of greenhouse gas emissions for integrated crop-livestock systems: Case study assessment in the Pantanal savanna highland, Brazil. Agric. Syst. 2015, 137, 206-219. [CrossRef]

41. Oliveira, S.N.; Carvalho Júnior, O.A.; Gomes, R.A.T.; Guimarães, R.F.; McManus, C.M. Deforestation analysis in protected areas and scenario simulation for structural corridors in the agricultural frontier of Western Bahia, Brazil. Land Use Policy 2017, 61, 40-52. [CrossRef]

42. Bationo, A.; Kihara, J.; Vanlauwe, B.; Waswa, B.; Kimetu, J. Soil organic carbon dynamics, functions and management in West African agro-ecosystems. Agric. Syst. 2007, 94, 13-25. [CrossRef]

43. Feller, C.; Fritsch, E.; Poss, R.; Valentin, C. Effet de la texture sur le stockage et la dynamique des matières organiques dans quelques sols ferrugineux et ferrallitiques (Afrique de l'ouest, en particulier). Cah. Orstom. 1991, 26, 25-36. Available online: https://core.ac.uk/download/pdf/39862285.pdf (accessed on 1 November 2019).

44. Christensen, B.T. Physical fractionation of soil and structural and functional complexity in organic matter turnover. Eur. J. Soil Sci. 2001, 52, 345-353. [CrossRef] 
45. Verdésio, J.J.; Torchelli, J.C.; Guerra, F.D. Caracterização Física e Agroeconomia da Região dos Cerrados do Oeste da Bahia; Instituto Interamericano de Cooperação para Agricultura: Brasília, Brazil, 1987; p. 32.

46. Francaviglia, R.; Coleman, K.; Whitmore, A.P.; Doro, L.; Urracci, G.; Rubino, M.; Ledda, L. Changes in soil organic carbon and climate change-Application of the RothC model in agro-silvo-pastoral Mediterranean systems. Agric. Syst. 2012, 112, 48-54. [CrossRef]

47. AIBA (Associação de Agricultores e Irrigantes da Bahia). Anuário da Região Oeste da Bahia-Safra 2016/2017; Editora Gazeta: Barreiras, Brazil, 2018; p. 53. Available online: http://aiba.org.br/wp-content/uploads/2018/ 06/anuario-16-17.pdf (accessed on 17 September 2019).

48. Galdos, M.V.; Calonego, J.C.; Rosolem, C.A.; Mooney, S.J. Modelling soil carbon dynamics under no-tillage and crop rotations in Brazil. In Proceedings of the International Symposium on Soil Organic Matter, Harpenden, UK, 3-7 September 2017. Rothamsted.

49. Carvalho, J.L.N.; Cerri, C.E.P.; Feigl, B.J.; Piccolo, M.C.; Godinho, V.P.; Cerri, C.C. Carbon sequestration in agricultural soils in the Cerrado region of the Brazilian Amazon. Soil Tillage Res. 2009, 103, 342-349. [CrossRef]

50. Silva Júnior, J.; Lopes, J.C.M. Agricultura Sequestradora de Carbono em Perímetros Agricultados com Algodão e Culturas Acessórias-Relatório Final No. 001/2015. Convênio, N; 284 FUNDEAGRO: Barreiras, Brazil, 2015; Available online: http://aiba.org.br/wp-content/uploads/2016/05/ARTIGO-SEQ-CARBONO-FINAL.pdf (accessed on 24 September 2019).

51. Srinivasarao, C.; Lal, R.; Kundu, S.; Babu, M.B.B.P.; Venkateswarlu, B.; Singh, A.K. Soil carbon sequestration in rainfed production systems in the semiarid tropics of India. Sci. Total Environ. 2014, 487, 587-603. [CrossRef]

52. Pittelkow, C.M.; Linquist, B.A.; Lundy, M.E.; Liang, X.; Groenigen, K.J.; Lee, J.; Gestel, N.; Six, J.; Venterea, R.T.; Kessel, C. When does no-till yield more? A global meta-analysis. Field Crop Res. 2015, 183, 156-168. [CrossRef]

53. Zdruli, P.; Lal, R.; Cherlet, M.; Kapur, S. New world atlas of desertification and issues of carbon sequestration, organic carbon stocks, nutrient depletion and implications for food security. In Carbon Management, Technologies, and Trends in Mediterranean Ecosystems; Erşahin, S., Kapur, S., Akça, E., Namlı, A., Erdoğan, H.E., Eds.; Springer: Mosbach, Germany, 2017; Volume 15, pp. 13-25. [CrossRef]

54. Ferreira, A.C.B.; Borin, A.L.D.C.; Lamas, F.M.; Bogiani, J.C.; Silva, M.A.S.; Silva Filho, J.L.; Staut, L.A. Soil carbon accumulation in cotton production systems in the Brazilian Cerrado. Acta Sci. 2020, 42, e43039. [CrossRef]

(C) 2020 by the authors. Licensee MDPI, Basel, Switzerland. This article is an open access article distributed under the terms and conditions of the Creative Commons Attribution (CC BY) license (http://creativecommons.org/licenses/by/4.0/). 